\title{
Advantage of a Narrow Spectrum Host Defense (Antimicrobial) Peptide Over a Broad Spectrum Analog in Preclinical Drug Development
}

\author{
Eszter Ostorhazi ${ }^{1}$, Ralf Hoffmann ${ }^{2}$, Nicole Herth ${ }^{2}$, John D. Wade ${ }^{3,4}$, Carl N. Kraus ${ }^{5}$ and \\ Laszlo Otvos Jr. ${ }^{1,5,6 *}$
}

${ }^{1}$ Institute of Medical Microbiology, Semmelweis University, Budapest, Hungary, ${ }^{2}$ Institute of Bioanalytical Chemistry, Leipzig University, Leipzig, Germany, ${ }^{3}$ Florey Institute of Neuroscience and Mental Health, University of Melbourne, Melbourne, VIC, Australia, ${ }^{4}$ School of Chemistry, University of Melbourne, Melbourne, VIC, Australia, ${ }^{5}$ Arrevus, Inc, Raleigh, NC, United States, ${ }^{6}$ OLPE, LLC, Audubon, PA, United States

\section{OPEN ACCESS}

Edited by:

Maria Luisa Mangoni,

Sapienza Università di Roma, Italy

Reviewed by:

Christian W. Gruber Medizinische Universität Wien, Austria

Norelle Daly,

James Cook University, Australia

*Correspondence:

Laszlo Otvos Jr.

lotvos@comcast.net

Specialty section: This article was submitted to

Chemical Biology,

a section of the journal

Frontiers in Chemistry

Received: 13 June 2018

Accepted: 30 July 2018

Published: 21 August 2018

Citation:

Ostorhazi E, Hoffmann R, Herth N, Wade JD, Kraus $C N$ and Otvos $L J r$

(2018) Advantage of a Narrow Spectrum Host Defense (Antimicrobial) Peptide Over a Broad Spectrum Analog in Preclinical Drug Development. Front. Chem. 6:359. doi: 10.3389/fchem.2018.00359
The APO-type proline-arginine-rich host defense peptides exhibit potent in vitro killing parameters against Enterobacteriaceae but not to other bacteria. Because of the excellent in vivo properties against systemic and local infections, attempts are regularly made to further improve the activity spectrum. A C-terminal hydrazide analog of the Chex1-Arg20 amide (ARV-1502) shows somewhat improved minimal inhibitory concentration against Moraxellaceae. Here we compared the activity of the two peptides as well as an inactive dimeric reverse amide analog in a systemic Acinetobacter baumannii infection. Only the narrow spectrum amide derivative reduced the 6-h blood bacterial burden by $>2 \log _{10}$ units reaching statistical significance $p=0.03$ at $5 \mathrm{mg} / \mathrm{kg}$ and 0.031 at $2 \mathrm{mg} / \mathrm{kg}$ administered intramuscularly). The hydrazide derivative, probably due to stronger activity on cell membranes, lysed erythrocytes at lower concentrations, and caused toxic effects at lower doses (10 mg/kg vs. $25 \mathrm{mg} / \mathrm{kg}$ ). In a limited study, the amide induced a $>5$-fold production of the anti-inflammatory cytokine IL-10 over untreated naiive mice and minor increases in the anti-inflammatory IL-4 and pro-inflammatory cytokines TNF- $\alpha$ and IL-6, in blood. The blood of hydrazide-treated mice exhibited significantly lowered levels of IL-10 and slightly decreased IL-4 and TNF- $\alpha$. These results suggest that the improved efficacy of the narrow-spectrum amide analog is likely associated with increased anti-inflammatory cytokine production and better stimulation of the immune system. Although blood IL-6 and TNF- $\alpha$ levels are frequently used as markers of potential toxicity in drug development, we did not observe any notable increase in mice receiving the toxic polyamide antibiotic colistin.

Keywords: Acinetobacter baumannii, anti-inflammatory cytokines, ARV-1502, bacteremia model, minimal inhibitory concentration, toxicity

\section{INTRODUCTION}

Current antimicrobial research aims to develop broad spectrum agents to help clinicians who must initiate empirical treatment regimen in systemic infections before the pathogens are even identified (Kollef, 2008). This notion comes from retrospective analysis of treatment success rates when small molecule antibiotic therapy is applied in hospitals (Tumbarello et al., 2007). To satisfy USA 
and European regulatory agencies, the in vitro minimal inhibitory concentration (MIC) clinical breakpoints should be below $16 \mathrm{mg} / \mathrm{L}$ against almost all pathogens, more preferably below 2-4 mg/L (EUCAST, 2018; US Department of Health Human Services Food Drug Administration, 2018). Antimicrobial peptides (AMPs) can seldom satisfy these recommendations, even if the osmolarity of test media is reduced for improved MIC readouts (Cudic et al., 2003).

Nevertheless, AMPs have been considered powerful drugs against many systemic infections in animal models since the 1990s (Hancock and Lehrer, 1998). A growing body of literature has demonstrated that AMPs have a plethora of activities on both bacteria and the hosts, immunostimulatory effects being equally, or more important than antimicrobial activity (Brandenburg et al., 2012; Otvos, 2016). Likewise, the innate immune system of the host can be upregulated by external AMP introduction (Knappe et al., 2016). The subsequently coined term, host defense peptide (HDP) (Nijnik and Hancock, 2009) is especially true for the proline-arginine-rich family of AMP, whose in vivo efficacy simply cannot be correlated with in vitro bacterial killing in topical infections (Ostorhazi et al., 2011a, 2013). The proline-arginine-rich HDP dimer A3-APO sterilizes wounds and intradermal tissues infected with Staphylococcus aureus or Propionibacterium acnes despite having no measurable in vitro MIC against these pathogens. The monomeric version of A3APO, referred to as Chex1-Arg20 or ARV-1502, has even greater efficacy in $P$. acnes (administered topically) or Acinetobacter baumannii systemic infection models (Ostorhazi et al., 2011b, 2013), in spite of high MIC values and having limited effects on bacterial membranes, both of which are drivers of broad spectrum in vitro functions (Cassone et al., 2008; Li et al., 2016).

The Chex1-Arg20 amide (ARV-1502) peptide is currently in development as a therapeutic measure against bacterial peritonitis. During our search for the optimal analog to enter pharmaceutical development, we compared the in vivo efficacy and toxicity parameters of a hydrazide C-terminal derivative of the same sequence. The hydrazide version was shown to have slightly reduced activity against sensitive Enterobacteriaceae including Escherichia coli and Klebsiella pneumoniae but improved MIC values against two largely resistant Gramnegative species, Acinetobacter baumannii (Moraxellaceae) and Pseudomonas aeruginosa (Pseudomonadeceae). Although the infectious agent in the current report was A. baumannii, the narrow spectrum Chex1-Arg20 amide outperformed the hydrazide in reducing the blood bacterial burden probably because of increased immunostimulatory activities (as measured by anti-inflammatory IL-10 production) compared to the broad spectrum analog.

\footnotetext{
Abbreviations: AMP, antimicrobial peptide; APO, all peptides optimized; Chex, 1-amino-cyclohexane carboxylic acid; CFU (or cfu), colony forming unit; Dab, 2,3diamino butyric acid; ELISA, enzyme-linked immunosorbent assay; HDP, hostdefense peptide; im, intramuscularly; IL, interleukin; ip, intraperitoneally; MHB, Muller-Hinton broth; NMRI, Naval Medical Research Institute; PBS, phosphate buffered saline; RBC, red blood cells; sc, subcutaneously; TI, therapeutic index; TNF, tumor necrosis factor.
}

\section{MATERIALS AND METHODS}

\section{Peptide Synthesis}

The peptides used in the current report were synthesized previously for other studies. Table 1 lists the peptides and their first publication references. All peptides were purified by reversed-phase high-performance liquid chromatography (RP-HPLC), characterized by matrix-assisted laser desorption/ionization mass spectroscopy, dialyzed twice from $1 \%$ acetic acid (to exchange trifluoroacetate counterions to acetate) and the actual peptide content was quantified by amino acid analysis or RP-HPLC.

\section{Measurement of Minimal Inhibitory Concentration}

MIC were measured in a liquid broth microdilution assay using sterile 96-well plates (Krizsan et al., 2015). Aqueous peptide solutions were serially twofold diluted (512 to $0.06 \mathrm{mg} / \mathrm{L}$ ) in $25 \%$ or undiluted Muller-Hinton broth (MHB) medium and mixed with overnight cultures diluted in the same media to 1.5 $\times 10^{7}$ cells $/ \mathrm{mL}$. The total volume was $100 \mu \mathrm{L}$ per well. The plates were incubated for $20 \pm 2 \mathrm{~h}$ at $37^{\circ} \mathrm{C}$. Optical density was measured at $595 \mathrm{~nm}$. The MIC was defined as the lowest peptide concentration at which the turbidity reading did not exceed that of medium only.

\section{Lysis of Red Blood Cells}

Blood was collected from a 47-year old healthy donor (EO). The plasma was discarded and the remaining cells were diluted in physiological salt solution 100 -fold. To $500 \mu \mathrm{L}$ of this suspension were added $50 \mu \mathrm{L}$ of test peptides or $1 \%(\mathrm{w} / \mathrm{v})$ Triton X-100 dissolved in distilled water. The peptide concentrations were: 100 , 200 , and $400 \mathrm{mg} / \mathrm{L}$. The vials were incubated at $37^{\circ} \mathrm{C}$ for $2 \mathrm{~h}$, the cells were centrifuged at 6,000 rpm for $1 \mathrm{~min}$, and the vials were photographed.

\section{Animals}

Three and a half-to-four and a half-week old female NMRI (Naval Medical Research Institute) BR mice (Toxi-Coop Zrt, Budapest, Hungary) were used throughout these studies. The mice were housed in plastic type 2 individually ventilated cages, 3 mice per cage, on softwood granules as bedding. The room was kept between 21 and $25^{\circ} \mathrm{C}$ with $12 \mathrm{~h}$ light: $12 \mathrm{~h}$ dark cycles. The animals had free access to tap water and pelleted rodent food. Upon completion of the experiments, surviving mice were euthanized by diethyl ether inhalation. Animals were maintained and handled in accordance with the recommendations of the Guidelines for the Care and Use of Laboratory Animals, and the protocols were approved by the Animal Care Committee of Semmelweis University (permission No.: PE/EA/60-8/2018).

\section{Infection Model}

Mice weighing $\sim 17-20 \mathrm{~g}$ (4 weeks old) were randomly divided into 6 groups, 5 mice in each group, and infected by intraperitoneal (ip) injection of $4.8 \mathrm{McF}$ arland $\left(2 \times 10^{7} \mathrm{CFU} / \mathrm{g}\right)$ A. baumannii BAA-1605 (Ostorhazi et al., 2017). Peptides were administered intramuscularly (im) at 5 or $2 \mathrm{mg} / \mathrm{kg}$ doses in phosphate buffered saline (PBS) $1 \mathrm{~h}$ after infection. Blood (10 
TABLE 1 | Peptides studied in the current study.

\begin{tabular}{|c|c|c|}
\hline & Sequence & Original description \\
\hline Chex1-Arg20 amide & $\begin{array}{l}\text { H-Chex-Arg-Pro-Asp-Lys-Pro-Arg-Pro-Tyr-Leu-Pro-Arg-Pro-Arg-Pro-Pro-Arg- } \\
\text { Pro-Val-Arg-NH2 }\end{array}$ & Noto et al., 2008 \\
\hline Hydrazide analog & $\begin{array}{l}\text { H-Chex-Arg-Pro-Asp-Lys-Pro-Arg-Pro-Tyr-Leu-Pro-Arg-Pro-Arg-Pro-Pro-Arg- } \\
\text { Pro-Val-Arg-NH-NH}\end{array}$ & Li et al., 2015 \\
\hline Reverse & $\begin{array}{l}\text { H-Chex-Arg-Val-Pro-Arg-Pro-Pro-Arg-Pro-Arg-Pro-Leu-Tyr-Pro-Arg-Pro-Lys- } \\
\text { Asp-Pro-Arg- } \mathrm{NH}_{2}\end{array}$ & Li et al., 2017a \\
\hline A3-APO dimer & $\begin{array}{l}\text { (H-Chex-Arg-Pro-Asp-Lys-Pro-Arg-Pro-Tyr-Leu-Pro-Arg-Pro-Arg-Pro-Pro-Arg- } \\
\text { Pro-Val-Arg)2-Dab }\end{array}$ & Otvos et al., 2005 \\
\hline
\end{tabular}

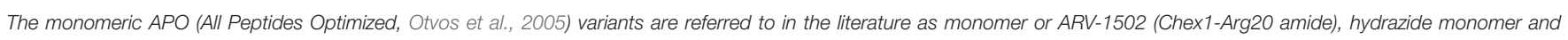
reverse. The peptides were not separately synthesized for this study; rather the preparations for the indicated publications were used.

$\mu \mathrm{L})$ was taken $6 \mathrm{~h}$ after infection for blood bacterial count determination. The blood was prevented from coagulation with ethylene diamine tetraacetic acid and the samples were serially diluted in $0.9 \%$ saline. Each dilution was cultured providing a detectable threshold of $10^{3} \mathrm{CFU} / \mathrm{mL}$. Survival was monitored at $24 \mathrm{~h}$ after infection.

Blood bacterial load reduction in the various groups was compared with unpaired Student's t-testing (SlideWrite, Encinitas, California, USA).

\section{In vivo Toxicity}

Mice (5 per group) were weighed before peptide administration. Peptides were administered im at 10, 25, 50, 75, and 100 $\mathrm{mg} / \mathrm{kg}$ doses. Mice were observed for behavioral effects for $24 \mathrm{~h}$ (Ostorhazi et al., 2010). Toxicity levels were identified as 1 , transient low-medium effects (reduced activity, cuddling, shivering) and 2, transient serious effects (complete lack of movements). After $24 \mathrm{~h}$, the mice were weighed again, ethically euthanized and gross necropsied for signs of obvious organ damage changes.

\section{Cytokine Quantitation}

NMRI mice were inoculated with the Chex1-Arg20 amide and hydrazide peptides in doses 2,5 or $10 \mathrm{mg} / \mathrm{kg}$ (one mouse for each dose and antibiotic for pro- and one mouse per dose and antibiotic for anti-inflammatory cytokines), the serum was collected after $24 \mathrm{~h}$ and was analyzed in duplicates for IL-4, IL10 , IL-6, and TNF- $\alpha$ content by using ELISA kits available for this purpose (Cedarlane Labs, Burlington, Ontario, Canada). Briefly, the sera and cytokine standards were loaded onto pre-coated 24 well (IL-4) or 96-well (IL-10, IL-4, and TNF- $\alpha$ ) plates, and the plates were reacted with biotinylated antibodies specific for the given cytokines. The cytokine concentration was quantified by using streptavidin-horseradish peroxidase and tetramethyl benzidine substrate solutions. Absorbance was read at $450 \mathrm{~nm}$. For IL- 6 and TNF- $\alpha$ determination, the test samples included blood of mice receiving $30 \mathrm{mg} / \mathrm{kg}$ imipenem or $10 \mathrm{mg} / \mathrm{kg}$ colistin subcutaneously (sc) both doses calculated as the allometrically scaled human clinical doses. The breadth of the assay was designed to fit all calibrating and test samples to plates pre-coated for each cytokine.

\section{RESULTS}

\section{MIC Measurements}

In previous studies, the Chex1-Arg20 amide (ARV-1502) was shown to inhibit the growth of E. coli and K. pneumoniae strains with $\sim 2$-fold reduction in MIC values (6.3 vs. $10 \mathrm{mg} / \mathrm{L}$ and 2 vs. $4.2 \mathrm{mg} / \mathrm{L}$ respectively) compared to the hydrazide analog (Li et al., 2015, 2017a). At the same time, the hydrazide was twofold more active than the amide against $A$. baumannii and $P$. aeruginosa (130 vs. $>250 \mathrm{mg} / \mathrm{L}$ and 72 vs. $140 \mathrm{mg} / \mathrm{L}$, respectively). The reverse peptide (Table 1) was completely inactive against even the otherwise sensitive strain K. pneumoniae (Li et al., 2017b). These results were observed by using the Lambert and Pearson growth curve analysis method (Lambert and Pearson, 2000), in which the MIC is provided by extrapolation of maximal growth against the antibiotic concentration. Regulatory agencies prefer no bacterial growth as MIC readout and thus we repeated the assays with a traditional broth microdilution assay in full and 25\% MHB media. In the current study, the amide retained the $\sim 2$-fold improvement in MIC values compared to the hydrazide against $K$. pneumoniae but was no less active than the hydrazide against A. baumannii (Table 2). Of note, the MIC remained above the reported MIC values even in quarter-strength $\mathrm{MHB}$. The studied A. baumannii strain with $64 \mathrm{mg} / \mathrm{L}$ MIC value can be considered resistant to both peptides. Our current studies verified the very weak or almost no in vitro activity of the reverse derivative (Table 2).

\section{Reduction of Bacterial Load in a Systemic Mouse A. baumannii Infection Model}

When mice are infected with A. baumannii 1605 and dosed with Chex1-Arg20 amide (ARV-1602) three times intramuscularly, the peptide prevents mortality in $>50 \%$ of the animals in spite of having no or minimal killing ability to this strain in vitro (Ostorhazi et al., 2011b). Here we used the same model to compare the in vivo protective effects of the Chex1Arg20 analogs, except that the mice received only 1 dose of peptide to better compare the blood bacterial counts early (6h) in the disease progression. If directly killing bacteria, AMPs are reported to act rapidly both in vitro and in vivo (Zasloff, 2002; Mohamed et al., 2016) and this is especially true for proline-arginine-rich peptides (Holfeld et al., 2017, 2018). Six 
TABLE 2 | Minimal inhibitory concentrations (MIC) of the APO peptide analogs against Gram-negative bacteria.

\begin{tabular}{|c|c|c|c|c|}
\hline Antibiotic & $\begin{array}{c}\text { MIC (mg/L) } \\
\text { in } 25 \% \mathrm{MHB}\end{array}$ & $\begin{array}{l}\text { MIC (mg/L) } \\
\text { in full MHB }\end{array}$ & $\begin{array}{c}\text { MIC (mg/L) } \\
\text { in } 25 \% \text { MHB }\end{array}$ & $\begin{array}{l}\text { MIC (mg/L) } \\
\text { in full MHB }\end{array}$ \\
\hline & K. pneumoniae & K. pneumoniae & A. baumannii & A. baumannii \\
\hline Chex1-Arg20 amide & 4 & $128(2)$ & 64 & $>512(>250)$ \\
\hline Chex1-Arg20 hydrazide & $8-16$ & $256(4.2)$ & 64 & $>512(130)$ \\
\hline reverse amide & $32-64$ & $>512$ (n.t.) & 64 & $>512$ (n.t.) \\
\hline Meropenem & 0.06 & 0.1 & 0.5 & 4 \\
\hline
\end{tabular}

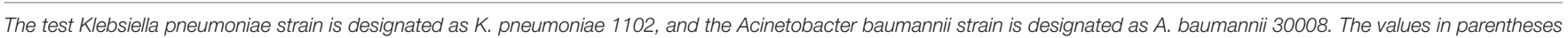

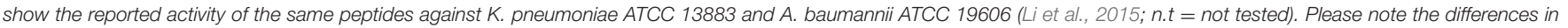

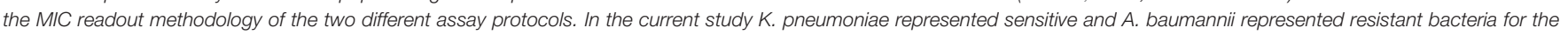

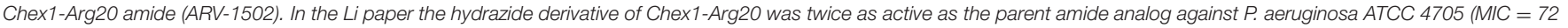
vs. $140 \mathrm{mg} / \mathrm{L})$. In the current test assay meropenem was used as a positive control.

hours after infection ( $5 \mathrm{~h}$ after peptide administration) the blood bacterial counts of untreated mice elevated to $3.1 \times 10^{8} \mathrm{CFU} / \mathrm{mL}$ (Figure 1). Mice treated with the reverse peptide exhibited no decrease in blood CFU levels $\left(2.9 \times 10^{8} \mathrm{CFU} / \mathrm{mL}\right)$. The Chex1-Arg20 amide and hydrazide peptides reduced the blood bacterial load in a dose-dependent manner. At $2 \mathrm{mg} / \mathrm{kg}$ hydrazide treatment the blood bacterial load was reduced to $1.7 \times 10^{7}$ $\mathrm{CFU} / \mathrm{mL}$ and at $5 \mathrm{mg} / \mathrm{kg}$ to $6.3 \times 10^{6} \mathrm{CFU} / \mathrm{mL}$ (Figure 1). However, neither of these values reached statistical significance. Statistically significant reduction in blood bacterial load was reached by using the amide version at both doses; $2 \mathrm{mg} / \mathrm{kg}$ resulting in $4.5 \times 10^{6} \mathrm{CFU} / \mathrm{mL}(p=0.031)$ and $5 \mathrm{mg} / \mathrm{kg}$ resulting in $2.4 \times 10^{6} \mathrm{CFU} / \mathrm{mL}(p=0.030)$.

While this study was not designed to monitor differences in survival (the single low dose therapy measure was not expected to markedly improve survival), we did find that peptide amide treatment resulted in a higher number of surviving animals early in the treatment course when dosed at $5 \mathrm{mg} / \mathrm{kg}(100 \%$ vs. $80 \%$ at $6 \mathrm{~h}$ ), and at the lower dose later in the study (20\% vs. $0 \%$ at $24 \mathrm{~h}$ dosed at $2 \mathrm{mg} / \mathrm{kg}$ ). Taken together, there was a signal that the Chex1-Arg20 amide version (ARV-1502) was more active in the animal model than the hydrazide analog, in spite of being a narrower spectrum derivative in vitro and not killing the test strain in the MIC measure.

\section{Toxicity}

Since the A3-APO dimer's broadened in vitro efficacy compared to the monomer amide is due to stronger effects on bacterial membranes (Cassone et al., 2008; Li et al., 2016), we hypothesized that the hydrazide similarly exhibits better MIC values against resistant strains because of increased activity on membranes. As broad spectrum AMPs are usually increasingly toxic (Bush et al., 2004), we wondered whether the hydrazide version is more toxic to mice, a phenomenon that could partially explain the lowered efficacy figures. Mice were inoculated im with $10,25,50,75$, and $100 \mathrm{mg} / \mathrm{kg}$ doses of peptides once. We monitored the weight gains and behavioral effects for $24 \mathrm{~h}$. Amide-treated peptides gained weight during the assay period, with lower doses resulting in higher weight increases (Figure 3). While the weight increases at 10 and $25 \mathrm{mg} / \mathrm{kg}$ were in the range of those of untreated animals, mice treated with higher doses gained less weight than normal female NMRI mice of similar age. The hydrazide analogtreated mice gained less weight when dosed at 10 and $25 \mathrm{mg} / \mathrm{kg}$ and lost increasingly more body mass at 50, 75, and $100 \mathrm{mg} / \mathrm{kg}$ peptide treatment. Clearly, the hydrazide analog appears to be more toxic than the amide version. In addition, while hydrazide analog-treated mice showed no visible signs of discomfort only at the $10 \mathrm{mg} / \mathrm{kg}$ dose, amide-treated mice had no discomfort at 10 and $25 \mathrm{mg} / \mathrm{kg}$ doses. All mice quickly recovered from toxicity symptoms and returned to normal activity levels within $2 \mathrm{~h}$.

The increased in vivo toxicity of the hydrazide analog should manifest in lysis of red blood cells at lower concentrations in vitro. Both peptides were reported not to have any effects on rat hepatoma and human embryonic kidney cells at 250 mg/L (Li et al., 2015, 2017b). However, at an MIC of $130 \mathrm{mg} / \mathrm{L}$ (converted from $\mu \mathrm{M}$ concentrations in the published reports), the therapeutic index (TI) would only be 2 . Here we increased the peptide concentration to $400 \mathrm{mg} / \mathrm{L}$ and were looking at effects on red blood cells from a healthy human donor. After incubation with peptides, the $1 \%$ red blood cell suspensions were photographed. The reverse and the amide analogs did not lyse the cells from any of the 100-400 $\mathrm{mg} / \mathrm{L}$ concentration range (Figure 2 shows the vials containing $400 \mathrm{mg} / \mathrm{L}$ peptides). In agreement with earlier studies, the hydrazide analog had little effect on the cells at $200 \mathrm{mg} / \mathrm{L}$, but in our assay it completely lysed the cells at $400 \mathrm{mg} / \mathrm{L}$ (Figure 2). In Figure 2, red blood cells alone and $1 \%$ Triton X-100 treated cells represent the negative and positive controls, respectively. In conclusion, when applied in a therapeutically meaningful concentration to identify the TI, the increased toxicity of the hydrazide version observed in vivo was verified by in vitro measurements.

\section{Production of Anti-inflammatory Cytokines}

One of the major mode of actions of HDP is the activation of immune responses, frequently involving anti-inflammatory cytokine production (Brandenburg et al., 2012; Otvos, 2016). Earlier we documented how the A3-APO dimer induces IL4 and IL-10 production in peripheral blood mononuclear cells (Ostorhazi et al., 2011a). In the current study we compared the increase of IL-4 and IL-10 in mouse blood after treatment with the monomeric amide and hydrazide peptides. The 24-h blood IL-4 content of peptide-treated mice was not significantly 


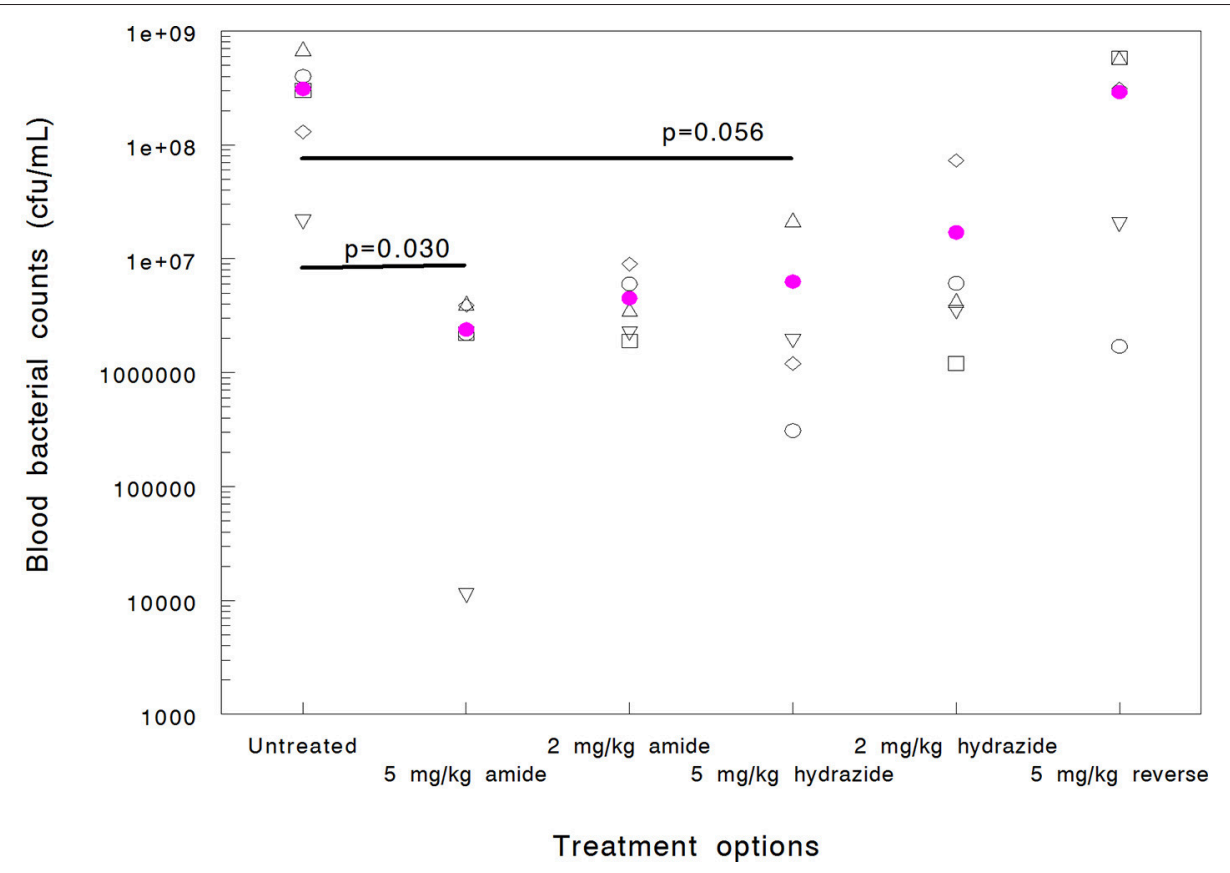

FIGURE 1 | Efficacy of APO peptide analogs in a mouse systemic Acinetobacter baumannii infection model as documented by blood bacterial counts (cfu/mL) measured $6 \mathrm{~h}$ after infection ( $5 \mathrm{~h}$ after treatment). Each group contained 5 randomly selected animals. Statistically significant reductions were observed for the Chex1-Arg20 amide (ARV-1502) at $5 \mathrm{mg} / \mathrm{kg}(p=0.030)$ and $2 \mathrm{mg} / \mathrm{kg}(p=0.031)$ doses. Hydrazide analog treatment did not yield statistically significant improvement ( $p=0.056$ at $5 \mathrm{mg} / \mathrm{kg}$ and 0.068 at $2 \mathrm{mg} / \mathrm{kg}$ ). In addition, one mouse in the $5 \mathrm{mg} / \mathrm{kg}$ hydrazide analog-treated group died before the 6 - $\mathrm{h}$ blood sampling (thus blood bacteria could not be enumerated). The reverse peptide was inactive in this measure.

different from those receiving physiological salt solution only (Figure 4). If any distinction is to be made, the IL-4 content of mice sera treated with the Chex1-Arg20 amide slightly increased with increasing dose and slightly decreased with increasing dose of the hydrazide. However, even at the highest dose of $10 \mathrm{mg} / \mathrm{kg}$, the IL- 4 concentrations differed by only about $10 \%$ from those of untreated mice. Significantly higher alterations were observed for the serum IL-10 content. Once again, as the dose of the amide peptide increased, the serum contained increased IL-10 levels, going from $129 \mathrm{pg} / \mathrm{mL}$ (untreated) to $228 \mathrm{pg} / \mathrm{mL}$ (at $2 \mathrm{mg} / \mathrm{kg}$ ), $433 \mathrm{pg} / \mathrm{mL}$ ( $5 \mathrm{mg} / \mathrm{kg}$ ), and $593 \mathrm{pg} / \mathrm{mL}$ (at $10 \mathrm{mg} / \mathrm{kg}$ ). At the $5 \mathrm{mg} / \mathrm{kg}$ therapy dose, the blood IL-10 concentration was $>3$ times of that of untreated mice (Figure 4). Conversely, with increasing the dose of the hydrazide analog to $5 \mathrm{mg} / \mathrm{kg}$ and $10 \mathrm{mg} / \mathrm{kg}$, the blood IL-10 decreased to $35 \mathrm{pg} / \mathrm{mL}$, and $1 \mathrm{pg} / \mathrm{mL}$ (Figure 4). At the therapy dose in the mouse of $5 \mathrm{mg} / \mathrm{kg}$, the IL-10 content was only about $27 \%$ of that of untreated animals.

As some HDP increase pro-inflammatory cytokine levels while others, such as LL-37, can raise both anti- and proinflammatory cytokines (Otvos, 2016), we also measured the blood IL- 6 and TNF- $\alpha$ content of mice treated with the Chex1Arg20 amide and hydrazide peptides. The blood TNF- $\alpha$ content of mice receiving no peptide was $\sim 17 \mathrm{pg} / \mathrm{mL}$, the lowest value in the calibrating standard curve. Upon amide-peptide treatment, the TNF- $\alpha$ content was slightly increased (by $2 \mathrm{pg} / \mathrm{mL}$ at 2 and $5 \mathrm{mg} / \mathrm{kg}$, and by $6 \mathrm{pg} / \mathrm{mL}$ at $10 \mathrm{mg} / \mathrm{kg}$ ) compared to untreated control animals (Table 3 ). At the same time points, the hydrazide analog-treated mice had slightly decreased blood TNF- $\alpha$ levels (by $1.5 \mathrm{pg} / \mathrm{mL}$ at $2 \mathrm{mg} / \mathrm{kg}, 2 \mathrm{pg} / \mathrm{mL}$ at $5 \mathrm{mg} / \mathrm{kg}$ and $5 \mathrm{pg} / \mathrm{mL}$ at $10 \mathrm{mg} / \mathrm{kg}$ ). The blood IL-6 content was less clearly associated with treatment arms. Once again, for Chex1-Arg20 amidetreated mice IL-6 was increased, but increasing doses produced smaller IL-6 elevations (Table 3). Regarding the hydrazide analog-treated mice, the blood IL-6 concentration increased slightly at the lowest dose of $2 \mathrm{mg} / \mathrm{kg}(3 \mathrm{pg} / \mathrm{mL})$, and decreased at the same level after $5 \mathrm{mg} / \mathrm{kg}$ and $10 \mathrm{mg} / \mathrm{kg}$ treatments. While no changes were found after $30 \mathrm{mg} / \mathrm{kg}$ imipenem treatment, a minor IL-6 increase was observed after exposure to $10 \mathrm{mg} / \mathrm{kg}$ colistin (Table 3). While these numbers remain significantly below the IL-10 increases, it was interesting to note that the more active amide analog produced higher levels of all cytokines studied than the less active hydrazide derivative. Allometrically scaled doses of colistin and imipenem induced lower TNF- $\alpha$ and almost unchanged IL-6 levels, comparable to those after Chex1-Arg20 hydrazide treatment (Table 3).

\section{DISCUSSION}

\section{In vitro Activity Differences}

While the reported activity of the hydrazide analog to A. baumannii is considered very weak (MIC $=130 \mathrm{mg} / \mathrm{L}$ ) (Li et al., 2015, 2017a), even at this low activity level in the current study we could not repeat the superiority of the hydrazide over the amide $(64 \mathrm{mg} / \mathrm{L}$ and $>512 \mathrm{mg} / \mathrm{L}$ in $25 \%$ 


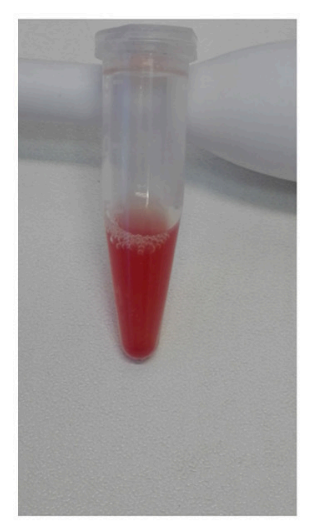

red blood cells

\section{Hydrazide 200 mg/L}

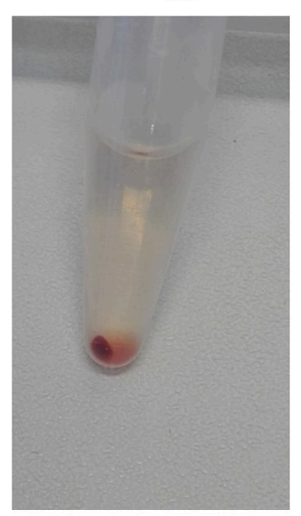

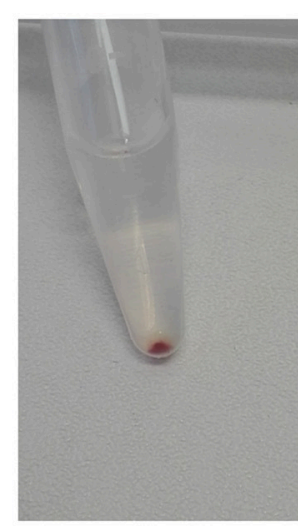

\section{Chex1-Arg20 amide $400 \mathrm{mg} / \mathrm{L}$}

Hydrazide $400 \mathrm{mg} / \mathrm{L}$

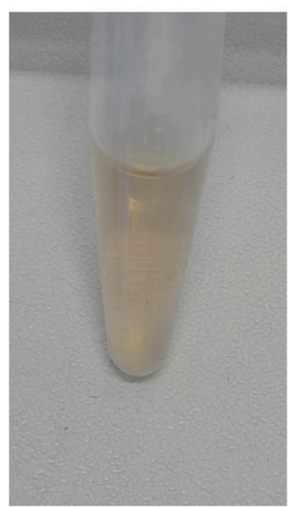

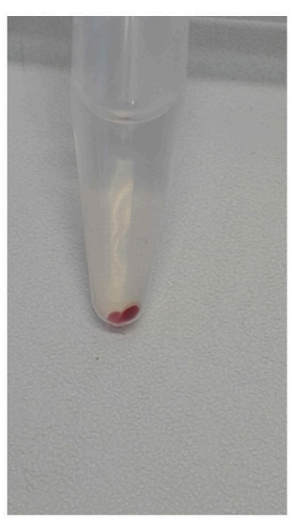

Reverse $400 \mathrm{mg} / \mathrm{L}$

\section{1\% Triton X}

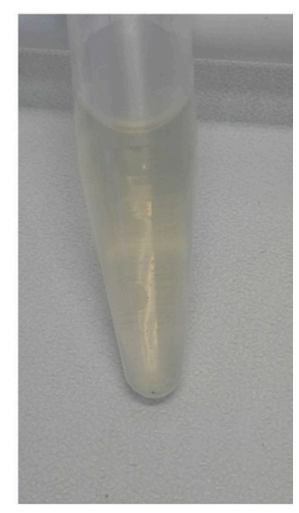

FIGURE 2 | Effect of APO monomeric peptides to a 1\% (v/v) human red blood cell (RBC) suspension. Top left: untreated RBC suspension. Top middle, top right, bottom left, and bottom middle: the suspension was treated with the given concentration of the peptides for $2 \mathrm{~h}$ and the cells were centrifuged. Bottom right: cells treated with $1 \%$ Triton X-100. The highest concentration of the hydrazide analog and the positive control surfactant dissolved the cells; the Chex 1 -Arg20 amide (ARV-1502) and reverse derivatives had no effect on RBC.

and full-strength MHB for both). The reasons for the lack of activity differences might be either alterations in the assay protocol (Lambert and Pearson vs. broth microdilution) or the identity of the actual A. baumannii strain. Even by using our standard assay protocol, we regularly observe a 4-fold difference in the MIC values among various A. baumannii strains when the assay is run in 25\% MHB. Our activity figures against Moraxellaceae, with Chex1-Arg20, its dimeric version A3-APO or one of the parent peptide to the APO analogs, pyrrhocoricin, always hover at the limit of detectability (Cudic et al., 2002; Ostorhazi et al., 2011b). Thus, the weak activity of the monomeric amide (this study) or no activity at all (earlier reports) can indeed reflect minor strain or assay protocol differences. In any event, taking all published data into consideration, the amide analog is increasingly active against sensitive strains and the hydrazide analog exhibits a broader (but less potent) activity spectrum.
The reverse peptide was less active than the amide and the hydrazide against the sensitive strain $K$. pneumoniae. One of the major modes of in vitro activity of the proline-arginine rich peptides, other than immunostimulation or inhibiting bacterial protein translation (Krizsan et al., 2014), is binding to the 70 $\mathrm{kDa}$ heat shock protein DnaK and inhibiting protein folding (Kragol et al., 2001). Measured by fluorescence polarization and dot-blot assays and using synthetic peptide fragments of DnaK, pyrrhocoricin binds both the conventional substrate-bonding pocket and the C-terminal multihelical lid. Binding to the lid appears to be stronger than that to the pocket providing strain and species-selectivity of pyrrhocoricin and its designer daughter variations (Kragol et al., 2001). Based on X-ray diffraction analysis, pyrrhocoricin binds to the substrate-binding pocket in both forward and reverse orientations (Zahn et al., 2013). The lack of any activity of the reverse APO peptide in killing bacteria indicates that binding to the pocket is not responsible for any 


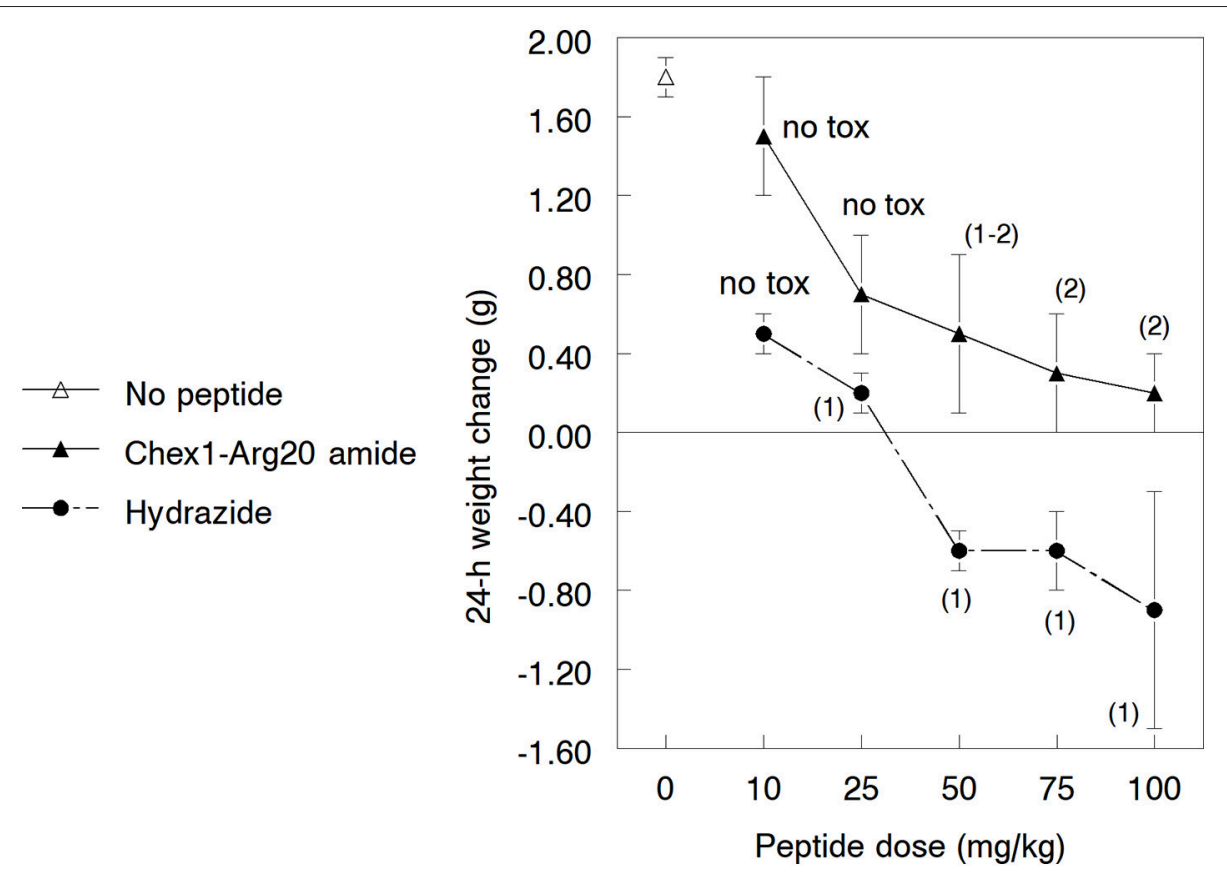

FIGURE 3 | Gross toxicity of the Chex1-Arg20 amide (ARV-1502) and the hydrazide analog to 3.5-4.5 weeks old growing NMRI mice. In every group, 5 mice were treated intramuscularly with the peptides and the weight change was measured after $24 \mathrm{~h}$. During the acclimatization period, the daily weight gain of the mice was 1.6-1.9 g. The usual weight gain of 3.5-4.5 weeks old normal female NMRI mice is 0.9-1.1 g/day. The numbers in parentheses indicate the visual discomfort of the animals: 1, transient low-medium effects - reduced activity, cuddling, shivering; 2 , transient serious effects - complete lack of movements. The mice returned to their normal activity patterns 60-90 min after treatment. Mice treated with the amide derivative not only maintained a higher weight than those treated with the hydrazide analog (these actually lost weight at higher doses) but the visual toxic effects started at higher peptide dose regimens.

antimicrobial activity. It is likely that X-ray diffraction captures a snapshot of fast binding under kinetic control whereas, insolution or mixed solution-membrane techniques reveal longerterm interactions under thermodynamic control, reflective of those processes observable in the presence of whole bacteria.

\section{In vitro and in vivo Toxicity}

Most research reports observe the in vitro toxicity of AMPs up to only $100 \mu \mathrm{M}$ that in our case represents $\sim 250 \mathrm{mg} / \mathrm{L}$. Given MIC values for Chex1-Arg20 against A. baumannii of $16-32 \mathrm{mg} / \mathrm{L}$, the range of past in vitro toxicity measurements do not even cover a TI of 10. AMPs or HDPs are usually administered in efficacy assays at higher doses than receptor-response modifying peptide drugs. Consequently, the in vitro toxicity assays must use higher concentrations than previously to cover reasonable TI ranges and mimic doses injected into the circulation of mice $(10 \mathrm{mg} / \mathrm{kg}$, a minimal intravenous (iv) dose of AMP, equals to $200 \mu \mathrm{g}$ drug injected directly into the $2 \mathrm{~mL}$ blood pool of mice or $100 \mathrm{mg} / \mathrm{L})$. Our generally observed iv toxicity level of $10-25 \mathrm{mg} / \mathrm{kg}$ (Szabo et al., 2010) is perfectly in line with the calculations presented above. We prefer im dosing to limit high peak concentrations and capitalize on a slow release into the circulation over a period of time ("depot effect," Ostorhazi et al., 2017), prolonging the exposure of the drug while keeping the maximum blood concentration lower. Indeed, not only prolinearginine-rich peptides such as those presented in the current report have a lower toxicity profile as well as improved activity when administered im, but this observation can be extended to other AMP families as well (Wu et al., 2014).

\section{Changes in Blood Cytokine Levels}

IL-10 is known to downregulate the expression of proinflammatory cytokines (Zhang and An, 2007). However, in our hands high levels of IL-10 expression upon peptide treatment did not result in TNF- $\alpha$ or IL- 6 expression below of those of untreated animals. In fact, both pro-inflammatory cytokine levels slightly increased after Chex1-Arg20 amide treatment. Potentially, the increased IL-10 levels served for limiting the upregulation of the pro-inflammatory cytokines and thereby suppressing immunopathology (Couper et al., 2008). It is interesting to note that the toxic signs of Chex1-Arg20 we observe in uninfected rats and dogs (Otvos et al., 2018) feature allergic effects and these perhaps signs of efficacy as manifested in IL-10 production rather than tissue toxicity findings.

A number of AMP/HDP families including the defensin and cathelicidin families activate innate immunity via proinflammatory signaling (Otvos, 2016). Systemic drug toxicities can be monitored by blood cytokine content with IL- 6 and TNF- $\alpha$ being responsible for the majority of the observed negative effects (Tarrant, 2010). Potentially, the observed high toxicity profiles of native and designer HDP can be correlated with significantly increased pro-inflammatory cytokine production. Indeed, the oncogenic properties of the cathelin-derived peptide LL-37 are linked to its pro-inflammatory activities (Otvos and Ostorhazi, 


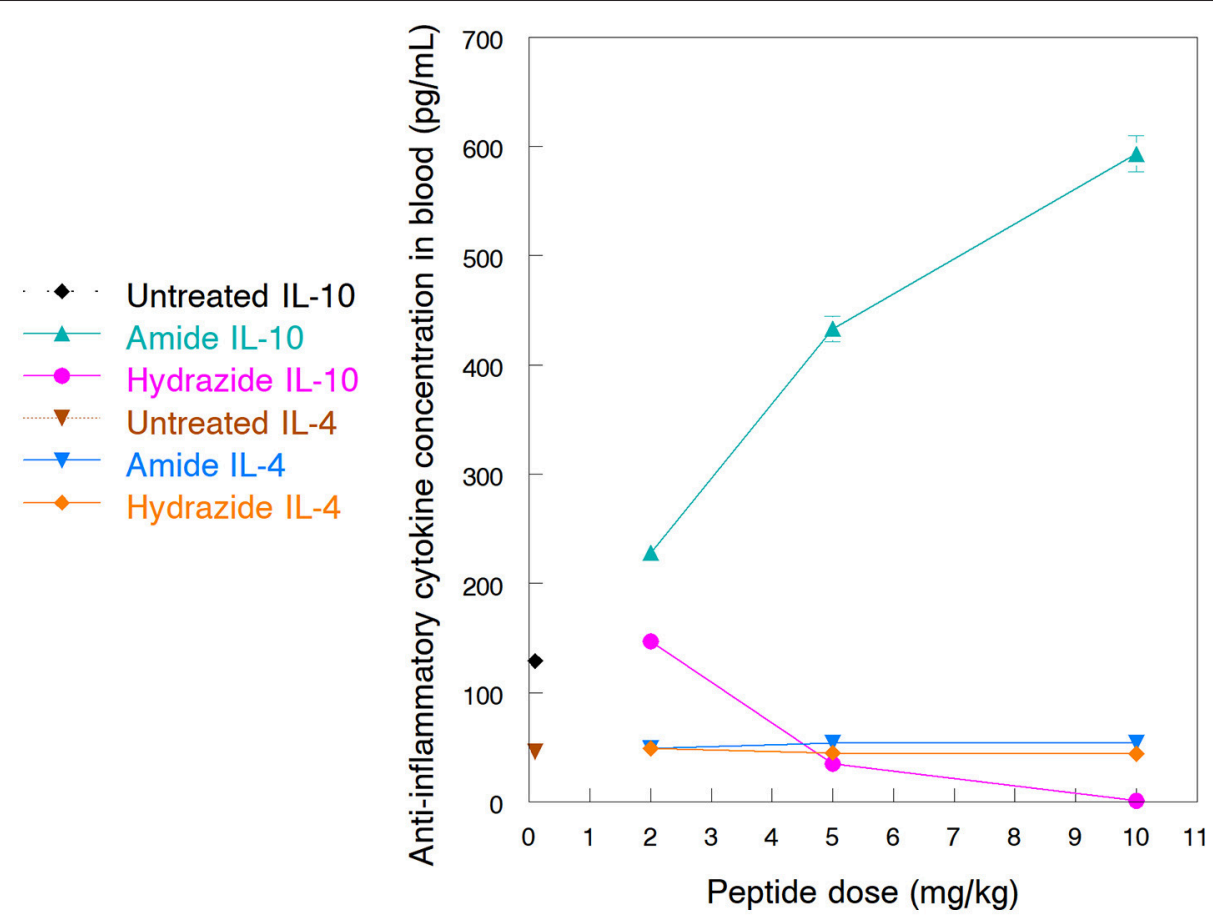

FIGURE 4 | Blood levels of anti-inflammatory cytokines after treatment of NMRI mice with Chex1-Arg20 amide (ARV-1502) and hydrazide peptides. One mouse per antibiotic and dose were intramuscularly (im) injected with 2,5 and $10 \mathrm{mg} / \mathrm{kg}$ peptide doses, and the blood was collected after $24 \mathrm{~h}$. IL- 4 and IL-10 concentrations were measured in duplicates with kits available for this purpose. The sample size was designed according to the well limitations of the pre-coated plates.

2015). Fortunately, many other peptide families currently under preclinical studies activate the immune system by exerting anti-inflammatory responses (Otvos, 2016) culminating in potent wound-healing activities (Otvos and Ostorhazi, 2015). In our current investigation these increases do not reflect toxicity because mice treated with colistin, an antibiotic with a well-characterized toxicity profile, still produced less TNF$\alpha$ and basically unchanged levels of IL- 6 than their untreated counterparts. In fact, in humans, colistin significantly decreases inflammatory cytokine responses to lipopolysaccharide (LPS) exposure in blood (Matzneller et al., 2017).

It is an intriguing question why the hydrazide peptide induced a reduced level of IL-10 expression in healthy mice. In general, antibiotics, including AMP, increase anti-inflammatory cytokine production in order to control inflammation and immunopathology, but this process is antibiotic dependent. For example, while vancomycin increases IL-10 production in THP-1 monocytes, linezolid and daptomycin act in exactly the opposite way (Bode et al., 2015). When LPS are present in the medium, all 3 antibiotics induce IL-10 release, unlike cephalosporins and ciprofloxacin that reduce IL-10 expression in the presence of LPS in human blood from healthy volunteers (Ziegeler et al., 2006). Another level of complexity comes from the fact that IL-10 itself can downregulate the expression of native AMP (human $\beta$-defensin) production in certain disease conditions (Howell et al., 2005). Apparently, the connection between cytokine level changes and AMP/HDP use is highly complex and greatly depends upon the identity of the peptides,
TABLE 3 | Changes in blood pro-inflammatory cytokine levels in mice after treatment with antibacterial agents.

\begin{tabular}{lcc}
\hline Treatment & $\begin{array}{c}\text { Concentration of TNF- } \alpha \\
(\mathbf{p g} / \mathbf{m L}) \text { in mouse blood }\end{array}$ & $\begin{array}{c}\text { Concentration of IL-6 } \\
(\mathbf{p g} / \mathbf{m L}) \text { in mouse blood }\end{array}$ \\
\hline Untreated control & $16.8 \pm 0.1$ & $12.4 \pm 0$ \\
Amide $2 \mathrm{mg} / \mathrm{kg} \mathrm{im}$ & $19.6 \pm 0.1$ & $17.1 \pm 0.1$ \\
Amide $5 \mathrm{mg} / \mathrm{kg} \mathrm{im}$ & $19.9 \pm 0.1$ & $16.2 \pm 0.1$ \\
Amide $10 \mathrm{mg} / \mathrm{kg} \mathrm{im}$ & $23.6 \pm 0.1$ & $12.8 \pm 0.1$ \\
Hydrazide $2 \mathrm{mg} / \mathrm{kg} \mathrm{im}$ & $15.1 \pm 0.1$ & $15.1 \pm 0.2$ \\
Hydrazide $5 \mathrm{mg} / \mathrm{kg} \mathrm{im}$ & $14.7 \pm 0$ & $9.5 \pm 0$ \\
Hydrazide $10 \mathrm{mg} / \mathrm{kg} \mathrm{im}$ & $11.8 \pm 0.1$ & $9.2 \pm 0.1$ \\
Colistin $10 \mathrm{mg} / \mathrm{kg} \mathrm{sc}$ & $13.6 \pm 0.1$ & $13.7 \pm 0$ \\
Imipenem $30 \mathrm{mg} / \mathrm{kg} \mathrm{sc}$ & $12.6 \pm 0$ & $11.5 \pm 0$ \\
\hline
\end{tabular}

The blood was collected $24 \mathrm{~h}$ after and TNF- $\alpha$ and IL-6 content was quantitated in duplicates with kits available for this purpose. One mouse was used for each dose of each antibiotic. Peptides were administered intramuscularly (im) and small molecule antibiotics subcutaneously (sc). The small molecule antibiotic doses correspond to the allometrically scaled human doses in current clinical practice. The allometrically scaled intended therapy dose of the Chex1-Arg20 (ARV-1502) is $5 \mathrm{mg} / \mathrm{kg}$ im in mice. The assay size was designed according to the well limitations of the pre-coated plates.

experimental conditions and other stimuli present in any given in vitro or in vivo system.

\section{Limitations of the Cytokine Profile Analysis}

The previous discussion topic leads us to the preliminary nature of the cytokine profile analysis upon treatment of mice with AMP/HDP. The major thrust of our paper is the comparison of 
the in vivo efficacy and toxicity parameters of in vitro narrow and broad spectrum peptides in order to select the optimal candidate for clinical development. With the limited analysis of cytokine expression we intended to contribute to the ever growing literature of potential alternative modes of action that ultimately make or break the ability of HDP to treat local and systemic infections. We studied only the two major anti- and two major pro-inflammatory cytokine levels; the evaluation of a comprehensive panel of cytokines is a next necessary step to fully understand the effects of HDP treatment to experimental animals and later patients. The peptides were administered im that activate muscular macrophages that are not present when the drugs are administered iv, a preferred way of therapy modality in the clinics. The study has to be expanded to a larger group size to be able to draw statistical conclusions as well as to include infected animals and bacterial breakdown products (LPS) that play roles in innate and adaptive immune reactions. Ultimately a detailed analysis of the changes and activation of immune cells upon AMP/HDP administration (Keitel et al., 2013) is a must to understand the role of immunostimulation upon peptide treatment as a therapy or prophylactic intervention.

\section{CONCLUDING REMARKS}

The current studies further support the notion that in vitro MIC evaluations of AMP/HDP have little prognostic value for efficacy in animal models of bacterial infections. Rather, combination of mild pro-inflammatory and strong anti-inflammatory activities suggest strong activation of the immune system of the hosts upon infection. Regarding in vitro toxicity evaluation, the applied peptide concentrations have to match desired TI values in vivo. For the specific case of amide to hydrazide conversion, from the very few published reports, one noted

\section{REFERENCES}

Bode, C., Muenster, S., Diedrich, B., Jahnert, S., Weisheit, C., Steinhagen, F., et al. (2015). Linezolid, vancomycin and daptomycin modulate cytokine production, Toll-like receptors and phagocytosis in a human in vitro model of sepsis. J. Antibiot. 68, 485-490. doi: 10.1038/ja. 2015.18

Brandenburg, L.-O., Merres, J., Albrecht, L.-J., Varoga, D., and Pufe, T. (2012). Antimicrobial peptides: multifunctional drugs for different applications. Polymers 4, 539-560. doi: 10.3390/polym40 10539

Bush, K., Macielag, M., and Weidner-Wells, M. (2004). Taking inventory: antibacterial agents currently at or beyond phase 1. Curr. Opin. Microbiol. 7, 466-776. doi: 10.1016/j.mib.2004.08.013

Cassone, M., Vogiatzi, P., La Montagna, R., De Olivier Inacio, V., Cudic, P., Wade, J. D., et al. (2008). Scope and limitations of the designer proline-rich antibacterial peptide dimer, A3-APO, alone or in synergy with conventional antibiotics. Peptides 29, 1878-1886. doi: 10.1016/j.peptides.2008. 07.016

Cavaillon, J. M. (1994). Cytokines and macrophages. Biomed. Pharmacother. 48, 445-453. doi: 10.1016/0753-3322(94)90005-1

Couper, K. N., Blount, D. G., and Riley, E. M. (2008). IL10: the master regulator of immunity to infection. J. slightly lowered in vivo opioid efficacy (Wang et al., 2013) and another observed increased antinociceptive tolerance (Wang et al., 2018) suggesting less efficient turnover, two features we could corroborate in the current report. Considering that the APO-type peptides increase macrophage production in infected tissues (Ostorhazi et al., 2013) and macrophages produce high levels of IL-10 during infection (Couper et al., 2008), the combined inflammatory cytokine profile can be considered both a result and a driving force of Chex1-Arg20 amide efficacy in protecting mammals from infection and regulating host immune responses. In support of our pilot study, from antiinflammatory cytokines macrophages do produce high IL-10 levels but not IL-4 (Cavaillon, 1994). Of particular interest, given the historic unreliability of MIC as predictor of in vivo activity for HDPs, there is a possibility of identifying other factors that may better correlate with this class of compounds. Cytokines, especially IL-10, may be such factors that clearly warrants further investigation.

\section{AUTHOR CONTRIBUTIONS}

EO, RH, JW, CK, and LO: assay design, data analysis, manuscript preparation; EO: in vivo efficacy, toxicity, and cytokine profile studies, $\mathrm{NH}$ : in vitro MIC measurements.

\section{ACKNOWLEDGMENTS}

This work was partially supported from grant R42 AI136065 from the National Institutes of Health. JW is an NHMRC (Australia) Principal Research Fellow (APP1117483). Research at the Florey Institute of Neuroscience and Mental Health is supported by the Victorian Government Operational Infrastructure Support Program.
Immunol. 180, 5771-5777. doi: 10.4049/jimmunol.180. 9.5771

Cudic, M., Condie, B. A., Weiner, D. J., Lysenko, E. S., Xiang, Z. Q., Insug, O., et al. (2002). Development of novel antibacterial peptides that kill resistant isolates. Peptides 23, 2071-2083. doi: 10.1016/S0196-9781(02) 00244-9

Cudic, M., Lockatell, C. V., Johnson, D. E., and Otvos, L. Jr. (2003). In vitro and in vivo activity of an antibacterial peptide analog against uropathogens. Peptides 24, 807-820. doi: 10.1016/S0196-9781(03)0 0172-4

EUCAST (2018). The European Committee on Antimicrobial Susceptibility, Testing Breakpoint Tables for Interpretation of Mics and Zone Diameters. Version 8.0. Available online at: http://www.eucast.org

Hancock, R. E., and Lehrer, R. (1998). Cationic peptides: a new source of antibiotics. Trends Biotechnol. 16, 82-88. doi: 10.1016/S0167-7799(97) 01156-6

Holfeld, L., Hoffmann, R., and Knappe, D. (2017). Correlating uptake and activity of proline-rich antimicrobial peptides in Escherichia coli. Anal. Bioanal. Chem. 409, 5581-5592. doi: 10.1007/s00216-017-0496-2

Holfeld, L., Knappe, D., and Hoffmann, R. (2018). Proline-rich antimicrobial peptides show a long-lasting post-antibiotic effect on Enterobacteriaceae. J. Antimicrob. Chemother. 73, 933-941. doi: 10.1093/jac/ $\mathrm{dkx} 482$ 
Howell, M. D., Novak, N., Bieber, T., Pastore, S., Girolomoni, G., Boguniewicz, M., et al. (2005). Interleukin-10 downregulates anti-microbial peptide expression in atopic dermatitis. J. Invest. Dermatol. 125, 738-745. doi: 10.1111/j.0022-202X.2005.23776.X

Keitel, U., Schilling, E., Knappe, D., Al-Mekhlafi, M., Petersen, F., Hoffmann, R., et al. (2013). Effect of antimicrobial peptides from Apis mellifera hemolymph and its optimized version Api88 on biological activities of human monocytes and mast cells. Innate Immun. 19, 355-367. doi: 10.1177/1753425912 462045

Knappe, D., Kabankov, N., Herth, N., and Hoffmann, R. (2016). Insect-derived short proline-rich and murine cathelicidin-related antimicrobial peptides act synergistically on Gram-negative bacteria in vitro. Fut. Med. Chem. 8, 1035-1045. doi: 10.4155/fmc2016-0083

Kollef, M. H. (2008). Broad-spectrum antimicrobials and the treatment of serious bacterial infections: getting it right up front. Clin. Infect. Dis. 47 (Suppl. 1), S3-S13. doi: 10.1086/590061

Kragol, G., Lovas, S., Varadi, G., Condie, B. A., Hoffmann, R., and Otvos, L. Jr. (2001). The antibacterial peptide pyrrhocoricin inhibits the ATPase actions of DnaK and prevents chaperone-assisted protein folding. Biochemistry 40, 3016-3026. doi: 10.1021/bi002656a

Krizsan, A., Prahl, C., Goldbach, T., Knappe, D., and Hoffmann, R. (2015). Short proline-rich antimicrobial peptides inhibit either the bacterial $70 \mathrm{~S}$ ribosome or the assembly of its large 50S subunit. Chem. Bio. Chem. 16, 2304-2308. doi: 10.1002/cbic. 201500375

Krizsan, A., Volke, D., Weinert, S., Sträter, N., Knappe, D., and Hoffmann, R. (2014). Insect derived proline-rich antimicrobial peptides kill bacteria by inhibiting bacterial protein translation at the $70 \mathrm{~S}$ ribosome. Angew. Chemie Int. Ed. Engl. 53, 12236-12239. doi: 10.1002/anie.2014 07145

Lambert, R. J., and Pearson, J. (2000). Susceptibility testing: accurate and reproducible minimum inhibitory concentration (MIC) and noninhibitory concentration (NIC) values. J. Appl. Microbiol. 88, 784-790. doi: 10.1046/j.1365-2672.2000.01017.x

Li, W., O’Brien-Simpson, N. M., Yao, S., Tailhades, J., Reynolds, E. C., Dawson, R. M., et al. (2017a). C-terminal modification and multimerization increase the efficacy of a proline-rich antimicrobial peptide. Chemistry 23, 390-396. doi: 10.1002/chem.201604172

Li, W., Sani, M. A., Jamasbi, E., Otvos, L. Jr, Hossain, M. A., Wade, J. D., et al. (2016). Membrane interactions of proline-rich antimicrobial peptide, Chex1-Arg20, multimers. Biochim. Biophys. Acta. 1858, 1236-1243. doi: 10.1016/j.bbamem.2016.02.035

Li, W., Sun, Z., O’Brien-Simpson, N. M., Otvos, L. Jr., Reynolds, E. C., Hossain, M. A., et al. (2017b). The effect of selective D- or N $\alpha$-methyl arginine substitution on the activity of the proline-rich antimicrobial peptide, Chex1-Arg20. Front Chem. 5:1. doi: 10.3389\%2Ffchem.2017.00001

Li, W., Tailhades, J., Hossain, M. A., O.-,Brien-Simpson, N. M., Reynolds, E. C., Separovic, F., et al. (2015). C-terminal modifications broaden the activity of the proline-rich antimicrobial peptide, Chex1-Arg20. Aust. J. Chem. 68, 1373-1378. doi: $10.1071 / \mathrm{CH} 15169$

Matzneller, P., Strommer, S., Drucker, C., Petroczi, K., Schörgenhofer, C., Lackner, E., et al.(2017). Colistin reduces LPS-triggered inflammation in a human sepsis model in vivo: a randomized controlled trial. Clin. Pharmacol. Ther. 101, 773-781. doi: 10.1002/cpt.582

Mohamed, F. M., Abdelkhale, A., and Seleem, M. N. (2016). Evaluation of short synthetic antimicrobial peptides for treatment of drug-resistant and intracellular Staphylococcus aureus. Sci. Rep. 6:29707 doi: 10.1038/ srep 29707

Nijnik, A., and Hancock, R. (2009). Host defence peptides: Antimicrobial and immunomodulatory activity and potential applications for tackling antibioticresistant infections. Emerg. Health Threats J. 2:e1. doi: 10.3402/ehtj.v2i0.7078

Noto, P. B., Abbadessa, G., Cassone, M., Mateo, G. D., Agelan, A., Wade, J. D., et al. (2008). Alternative stabilities of a proline-rich antibacterial peptide in vitro and in vivo. Protein Sci. 17, 1249-1255. doi: 10.1110/ps.0 34330

Ostorhazi, E., Holub, M. C., Rozgonyi, F., Harmos, F., Cassone, M., Wade, J. D., et al. (2011a). Broad-spectrum antimicrobial efficacy of peptide
A3-APO in mouse models of multidrug-resistant wound and lung infections cannot be explained by in vitro activity against the pathogens involved. Int. J. Antimicrob. Agents 37, 480-484. doi: 10.1016/j.ijantimicag.2011. 01.003

Ostorhazi, E., Horvath, A., Szabo, D., and Otvos, L.,Jr. (2017). Transdermally administered proline-arginine-rich host defense peptides show systemic efficacy in a lethal mouse bacteremia model. Amino Acids. 49, 1647-1651. doi: 10.1007/s00726-0172457-7

Ostorhazi, E., Rozgonyi, F., Szabo, D., Binas, A., Cassone, M., Wade, J. D., et al. (2011b). Intramuscularly administered peptide A3-APO is effective against carbapenem-resistant Acinetobacter baumannii in mouse models of systemic infections. Biopolymers 96, 126-129. doi: 10.1002/bip. 21443

Ostorhazi, E., Rozgonyi, F., Sztodola, A., Harmos, F., Kovalszky, I., Szabo, D. Jr., et al. (2010). Preclinical advantages of intramuscularly administered peptide A3-APO over existing therapies in Acinetobacter baumannii wound infections. J. Antimicrob. Chemother. 65, 2416-2422. doi: 10.1093/jac/ dkq337

Ostorhazi, E., Voros, E., Nemes-Nikodem, E., Pinter, D., Sillo, P., Mayer, B., et al. (2013). Rapid systemic and local treatments with the antibacterial peptide dimer A3-APO and its monomeric metabolite eliminate bacteria and reduce inflammation in intradermal lesions infected with Propionibacterium acnes and methicillin-resistant Staphylococcus aureus. Int. J. Antimicrob. Agents 42, 537-543. doi: 10.1016/j.ijantimicag.2013. 08.001

Otvos, L. Jr. (2016). Immunomodulatory effects of anti-microbial peptides. Acta Microbiol. Immunol. Hung. 63, 257-277. doi: 10.1556/030.63. 2016.005

Otvos, L. Jr., Ostorhazi, E., Szabo, D., Zumbrun, S. D., Miller, L. L., Halasohoris, S. A., et al. (2018). Synergy between proline-rich antimicrobial peptides and small molecule antibiotics against selected Gram-negative pathogens in vitro and in vivo. Front. Chem. Biol. 2:48.doi: 10.3389/fchem.2018. 00309

Otvos, L. Jr., Wade, J. D., Lin, F., Condie, B. A., Hanrieder, J., and Hoffmann, R. (2005). Designer antibacterial peptides kill fluoroquinoloneresistant clinical isolates. J. Med. Chem. 48, 5349-5359. doi: 10.1021/jm05 $0347 \mathrm{i}$

Otvos, L. Jr. and Ostorhazi, E. (2015). Therapeutic utility of antibacterial peptides in wound healing. Expert Rev. AntiInfect Ther. 13, 871-881. doi: 10.1586/14787210.2015.10 33402

Szabo, D., Ostorhazi, E., Binas, A., Rozgonyi, F., Kocsis, B., Cassone, M., et al. (2010). The designer proline-rich antibacterial peptide A3-APO is effective against systemic Escherichia coli infections in different mouse models. Int. J. Antimicrob. Agents 35, 357-361. doi: 10.1016/j.ijantimicag.2009. 10.015

Tarrant, J. (2010). Blood cytokines as biomarkers of in vivo toxicity in preclinical safety assessment: considerations for their use. Toxicol. Sci. 117, 4-16 doi: 10.1093/toxsci/kfq134

Tumbarello, M., Sanguinetti, M., Montuori, E., Trecarichi, E. M., Posteraro, B., Fiori, B., et al. (2007). Predictors of mortality in patients with bloodstream infections caused by extended-spectrum-beta-lactamase-producing Enterobacteriaceae: Importance of inadequate initial antimicrobial treatment. Antimicrob. Agents Chemother. 51, 1987-1994. doi: 10.1128/AAC.01509-06

US Department of Health and Human Services Food and Drug Administration (2018). Microbiology Data for Systemic Antibacterial Drugs - Development, Analysis, and Presentation; Guidance for Industry. Available online at: https:// www.fda.gov/downloads/Drugs/GuidanceComplianceRegulatoryInformation/ Guidances/UCM182288.pdf

Wang, C., Yang, D. J., Yuan, B. Y., and Wang, Y. (2018). C-terminal hydrazide modification changes the spinal antinociceptive profiles of endomorphins in mice. Peptides 99, 128-133. doi: 10.1016/j.peptides.2017.08.009

Wang, C. L., Ren, Y. K., Xiang, Q., Wang, Y., Gu, N., Lu, C., et al. (2013). Characterization of opioid activities of endomorphin analogs with C-terminal amide to hydrazide conversion. Neuropeptides 47, 297-304. doi: 10.1016/j.npep.2013.09.001 
Wu, X., Wang, Z., Li, X., Fan, Y., He, G., Wan, Y., et al. (2014). In vitro and in vivo activities of antimicrobial peptides developed using an amino acid-based activity prediction method. Antimicrob. Agents Chemother. 58, 5342-5349. doi: 10.1128/AAC.02823-14

Zahn, M., Berthold, N., Kieslich, B., Knappe, D., Hoffmann, R., and Sträter, N. (2013). Structural studies on the forward and reverse binding modes of peptides to the chaperone DnaK. J. Mol. Biol. 425, 2463-2479. doi: 10.1016/j.jmb.2013.03.041

Zasloff, M. (2002). Antimicrobial peptides of multicellular organisms. Nature 415, 389-395. doi: $10.1038 / 415389$ a

Zhang, J.-M., and An, J. (2007). Cytokines, inflammation and pain. Int. Anesthesiol. Clin.45, 27-37. doi: 10.1097/AIA.0b013e318034194e

Ziegeler, S., Raddatz, A., Hoff, G., Buchinger, H., Bauer, I., Stockhausen, A., et al. (2006). Antibiotics modulate the stimulated cytokine response to endotoxin in a human ex vivo, in vitro model. Anaesthes. Scand. 50, 1103-1110. doi: 10.1111/j.1399-6576.2006. 01112.x
Conflict of Interest Statement: CK is the Chief Executive Officer of Arrevus, Inc, a biotechnology company focusing on the clinical development of the APO-type proline-arginine-rich hose defense peptides. LO is an advisor to Arrevus and is the inventor of an issued patent on the Chex1-Arg20 peptide that is licensed by Arrevus.

The remaining authors declare that the research was conducted in the absence of any commercial or financial relationships that could be construed as a potential conflict of interest.

Copyright (๑) 2018 Ostorhazi, Hoffmann, Herth, Wade, Kraus and Otvos. This is an open-access article distributed under the terms of the Creative Commons Attribution License (CC BY). The use, distribution or reproduction in other forums is permitted, provided the original author(s) and the copyright owner(s) are credited and that the original publication in this journal is cited, in accordance with accepted academic practice. No use, distribution or reproduction is permitted which does not comply with these terms. 